\title{
Lama hidup, Keperidian, serta Kemampuan Memangsa Curinus coeruleus Mulsant (Coleoptera: Coccinellidae) terhadap Bemisia tabacigennadius (Homoptera: Aleyrodidae)
}

\author{
Agung Triantoro Riyanto ${ }^{1}$, Sudarjat ${ }^{2}$ \\ ${ }^{1}$ Alumnus Jurusan Hama Penyakit Tumbuhan, Fakultas Pertanian, Universitas Padjadjaran \\ ${ }^{2} J u r u s a n$ Hama Penyakit Tumbuhan \\ Fakultas Pertanian, Universitas Padjadjaran \\ Jln Raya Jatinangor km 21 Bandung 40600 \\ Korespondensi : ajat_proteksi@yahoo.com
}

\author{
ABSTRACT \\ Longevity, Fecundity and Predation of Curinus coeruleus Mulsant \\ (Coleoptera; Coccinellidae) on Bemisia tabaci Gennadius (Homoptera; Aleyrodidae)
}

The objectives of the research were to observe the longevity and fecundity of $C$. coeruleus feeding on B. tabaci nymph, and the predation of $C$. coeruleus on $B$. tabaci nymph at different density level. The experiment was arranged in Factorial Completely Randomized Block Design with two factors i.e. developmental stage of predator C.coeruleus $\left(1^{\text {st }}\right.$ instars larvae, $2^{\text {nd }}$ instars larvae, $3^{\text {rd }}$ instars larvae, $4^{\text {th }}$ instars larvae, female adult, and male adult) and prey density of nymph B. tabaci (60 nymphs, 120 nymphs and 240 nymphs). The Effect of $B$. tabaci prey to the $1^{\text {st }}$ instars larvae stage of $C$. coeruleus was shown at 8-10 days, the $2^{\text {nd }}$ instars larvae stage was 4-6 days, the $3^{\text {rd }}$ instars larvae stage was 5-8 days, the $4^{\text {th }}$ instars larvae was 9-12 days, the pre-pupae stage was 2-3 days, the pupae stage was 6-8 days, the female was 63-76 days and the male was 52-69 days. The female of $C$. coeruleus laid 11-116 eggs at 54,55-81,03\% of hatching percentage. A female laid eggs 2-6 times during its life. The egg stage was 6-7 days. At 240 prey density of B. tabaci nymph, $4^{\text {th }}$ instar larvae was able to feed up to 102,5 B. tabaci nymph/larvae/days.

Key words: Curinus coeruleus, Bemisia tabaci, longevity, fecundity, predation.

\begin{abstract}
ABSTRAK
Penelitian ini bertujuan untuk mengetahui lama hidup pada setiap tahap perkembangan dan keperidian Curinus coeruleus serta kemampuan memangsa $C$. coeruleus terhadap berbagai kepadatan nimfa Bemisia tabaci. Metode yang digunakan dalam percobaan ini yaitu Rancangan Acak Kelompok Pola Faktorial, yang terdiri dari 2 faktor, yaitu: faktor tahap perkembangan predator C.coeruleus (larva instar-1, larva instar-2, larva instar-3, larva instar-4, imago betina dan imago jantan) dan faktor kepadatan mangsa nimfa $B$. tabaci $(60,120$, dan 240 ekor mangsa). Hasil percobaan menunjukkan bahwa lama stadium larva instar-1 $C$. coeruleus berkisar antara 8-10 hari, larva instar-2 berkisar 4-6 hari, larva instar-3 berkisar 5-8 hari, larva instar-4 berkisar 9-12 hari, prapupa berkisar 2-3 hari, pupa berkisar 6-8 hari, lama hidup imago betina berkisar $63-76$ hari dan lama hidup imago jantan berkisar antara 52-69 hari. Kemampuan C. coeruleus meletakkan telur selama hidupnya berkisar antara 11-116 butir dengan persentase penetasan telur 54,55-81,03\%, peletakan telur terjadi 2-6 kali. Masa inkubasi telur berkisar antara 6-7 hari. Jumlah
\end{abstract}


pemangsaan tertinggi terjadi pada perlakuan larva instar-4 dengan kepadatan mangsa 240 ekor nimfa B. tabaci, yaitu rata-rata 102,5 ekor nimfa $B$. tabaci larva $^{-1}$ hari $^{-1}$.

Kata kunci: Curinus coeruleus, Bemisia tabaci, lama hidup, keperidian, kemampuan memangsa.

\section{PENDAHULUAN}

Bemisia tabaci Gennadius (Homoptera: Aleyrodidae) merupakan salah satu hama penting di dunia yang mendapat perhatian khusus. B. tabaci merupakan hama polifag yang menyerang berbagai jenis tanaman, antara lain tanaman hias, sayuran, buah-buahan maupun tumbuhan liar atau gulma (Greathead, 1986 dalam Mau \& Kessing, 1992). Pada tahun 1984 tingkat kerusakan pada pertanaman tembakau di Bojonegoro yang disebabkan oleh $B$. tabaci mencapai $30 \%$ dari seluruh areal pertanaman, lebih rendah bandingkan dengan tahun-tahun sebelumnya yang hanya 2-3\% (Trisusilawati, 1989 dalam Aidawati, 2001).

Populasi organisme di alam berada dalam keadaan seimbang pada jenjang populasi tertentu. Hal ini disebabkan oleh faktor-faktor lingkungan dan faktor dalam populasi yang mengendalikan perkembangan populasi (Sosromarsono \& Untung, 2006). Salah satu faktor lingkungan adalah musuh alami baik berupa predator, parasitoid dan patogen dikenal sebagai faktor pengatur dan pengendali populasi serangga hama. Pengaturan musuh alami ini terhadap populasi serangga hama tergantung pada kepadatan (density dependent) (Untung, 2001). Wagiman (1996) mengemukakan bahwa hubungan saling tergantung antara pemangsa dan mangsanya merupakan salah satu sifat predator yang dikehendaki. Tanggapan pemangsa terhadap perubahan kepadatan populasi mangsa dibedakan menjadi tanggap fungsional dan tanggap numerikal. Tanggap fungsional adalah perubahan banyaknya mangsa yang dimangsa oleh seekor pemangsa pada kepadatan populasi mangsa yang berbeda, sedangkan tanggap numerikal adalah perubahan kepadatan populasi pemangsa pada kepadatan populasi mangsa yang berbeda-beda (Solomon, 1949 dalam Wagiman, 1996).

Sheppard \& Harwood (2005) dan Mau \& Kessing (1992) melaporkan bahwa B. tabaci memiliki multipredator, salah satu diantaranya yaitu golongan Coccinellidae. Curinus coeruleus Mulsant (Coleoptera: Coccinellidae) merupakan musuh alami yang efektif dalam menekan populasi Heteropsylla cubana Crawford (Homoptera: Psyllidae) di berbagai negara (Irataktamath, 2002). Menurut Fatah (2007), C. coeruleus merupakan salah satu predator yang ditemukan pada pertanaman kacang buncis yang terserang B. tabaci di daerah Kecamatan Ciwidey, Kabupaten Bandung, dan keberadaannya di alam cukup melimpah.

Pengamatan tingkah laku dan biologi predator merupakan kunci yang penting untuk memahami cara hidup predator dan pengaruh predator terhadap dinamika populasi inang atau mangsanya. Selain itu, pengamatan tersebut juga berguna dalam menentukan predator yang memiliki potensi paling tinggi dalam mengendalikan serangga hama dan untuk mengevaluasi kemampuan predator setelah dilepaskan di lapangan (Luck, 1990 dalam Dixon, 2000).

Tingkah laku, lama hidup dan jumlah $C$. coeruleus yang dihasilkan pada generasi kedua, serta kemampuan memangsa dan tanggapannya terhadap peningkatan populasi hama diharapkan dapat diketahui dengan dilaksanakannya penelitian ini.

\section{BAHAN DAN METODE}

Metode yang digunakan untuk percobaan ini adalah metode percobaan dengan menggunakan rancangan acak kelompok pola faktorial, yang terdiri dari 2 faktor. Faktor pertama adalah tahap perkembangan predator $C$. coeruleus $(\mathrm{S})$ yang terdiri dari 6 level, yaitu: $\mathrm{s} 1=$ Larva instar-1 C. coeruleus, s2 = Larva instar $-2 C$. coeruleus, $\mathrm{s} 3=$ Larva instar $-3 C$. coeruleus, $\mathrm{s} 4=$ Larva instar-4 C. coeruleus, $\mathrm{s} 5=$ Imago betina $C$. coeruleus, $\mathrm{s} 6=$ Imago jantan $C$. coeruleus . Faktor kedua adalah kepadatan mangsa nimfa $B$. tabaci $(\mathrm{N})$ yang terdiri dari 3 level, yaitu: $\mathrm{n}_{1}=60$ ekor nimfa $B$. tabaci, $\mathrm{n}_{2}=120$ ekor nimfa $B$. tabaci,n3 = 240 ekor nimfa $B$. tabaci . Pada setiap perlakuan, $C$. coeruleus dilaparkan selama 24 jam.

Benih tanaman labu dan kacang merah ditanam di dalam polibag ukuran $2 \mathrm{~kg}$ secara terpisah dengan menggunakan media tanah yang dicampur pupuk kandang dengan perbandingan 3:1. Apabila tanaman labu dan kacang merah telah cukup untuk 
digunakan sebagai media hidup B. tabaci (kira-kira dua minggu setelah tanam, saat daun sudah mulai tumbuh), maka tanaman dipindahkan ke dalam kurungan kasa yang telah disiapkan di dalam rumah kaca.

C. coeruleus dikembangbiakkan di dalam kurungan kasa yang berisi tanaman labu dan kacang merah. C. coeruleus tersebut diberi makan kutu loncat lamtoro, myzus atau aphid yang berasal dari pertanaman lamtoro, sawi dan jeruk di Jatinangor. Pemberian makanan diberikan secara bergantian disesuaikan dengan ketersediannya di lapangan. $B$. tabaci diinfestasikan pada tanaman labu dan kacang merah di dalam kurungan kasa agar berkembangbiak. Penggantian tanaman dilakukan apabila tanaman mati atau layu.

Variabel respons yang diamati adalah: 1) lama hidup $C$. coeruleus, 2) keperidian $C$. coeruleus, dan 3) tingkat predasi $C$. coeruleus terhadap nimfa $B$. tabaci. Data dianalisis dengan menggunakan analisis ragam, nilai $\mathrm{F}$ hitung yang diperoleh dibandingkan dengan nilai $\mathrm{F}$ hitung tabel pada taraf 5\%. Untuk mengetahui adanya perbedaan pengaruh antar perlakuan, data yang diperoleh dianalisis dengan menggunakan Uji Jarak Berganda Duncan pada taraf nyata 5\%.

\section{Waktu Perkembangan dan Lama waktu hidup $C$. coeruleus}

C. coeruleus yang digunakan adalah $C$. coeruleus yang diujikan pada percobaan tingkat predasi dengan mengamati lama waktu hidup pada setiap tahap perkembangan. Imago yang telah selesai diujikan pada percobaan tingkat predasi, yaitu pada umur 8 hari hingga selanjutnya diberi mangsa nimfa $B$. tabaci dengan jumlah secukupnya hingga diketahui lama waktu hidupnya.

\section{Keperidian C. coeruleus}

Sebanyak 3 pasang imago betina dan jantan C. coeruleus yang baru keluar dari pupa dipisahkan. Setiap pasang imago diinfestasikan ke dalam satu stoples dan diberi mangsa nimfa $B$. tabaci dengan jumlah 120 ekor, 240 ekor dan 480 ekor (berdasarkan pada kepadatan mangsa pada percobaan tingkat predasi) serta diberi kertas tisue secukupnya sebagai tempat peletakan telur. Pemberian mangsa dilakukan setiap hari hingga diketahui jumlah telur yang dihasilkan imago betina $C$. coeruleus selama hidupnya. Telur yang dihasilkan oleh imago betina dipisahkan ke dalam stoples berbeda dan dihitung jumlahnya.

\section{Tingkat predasi $C$. coeruleus}

Seluruh perlakuan masing-masing ditempatkan pada satu stoples. Masing-masing perlakuan diinfestasikan satu ekor $C$. coeruleus dan nimfa $B$. tabaci. $C$. coeruleus yang digunakan adalah C. coeruleus yang baru menetas dari telur (untuk larva instar-1), baru ganti kulit (untuk larva instar-2, larva instar-3 dan larva instar-4), dan yang telah melewati tahap pupa (untuk imago). Nimfa B. tabaci yang digunakan adalah nimfa instar-4 yang jumlahnya disesuaikan dengan masing-masing perlakuan. Sebelum diujikan, C. coeruleus dilaparkan terlebih dahulu selama 24 jam. Percobaan dilakukan selama waktu hidup $C$. coeruleus kecuali pada imago, percobaan dilakukan selama 7 hari. Pengamatan dan penggantian nimfa $B$. tabaci yang diberikan pada $C$. coeruleus dilakukan pada setiap pukul 06.00 WIB selama waktu hidup $C$. coeruleus. Pada saat percobaan suhu rata-rata rumah kaca berkisar antara $22,6^{\circ} \mathrm{C}-27,2^{\circ} \mathrm{C}$, sedangkan rata-rata kelembaban berkisar antara 61,9\%-68,1\%.

\section{HASIL DAN PEMBAHASAN}

\section{Waktu Perkembangan dan Lama Hidup C. coeruleus}

Larva instar-1 dan larva instar-4 memiliki waktu perkembangan yang paling lama yaitu berturut-turut berkisar antara 8-10 hari dengan ratarata 9,33 hari dan 9-12 hari dengan rata-rata 10,44 hari. Lama hidup imago betina berkisar antara 6376 hari dengan rata-rata 71 hari; dan imago jantan berkisar antara 52-69 hari dengan rata-rata 61,44 hari (Tabel 1). Umur imago yang lama berimplikasi pada kemampuan memangsa inang dan reproduksi yang lebih tinggi. 
Tabel 1. Waktu perkembangan dan lama hidup berbagai tahap perkembangan C. coeruleus

\begin{tabular}{clcc}
\hline No & Tahap Perkembangan & stadium $(\mathrm{x} \pm \mathrm{SD})($ hari) & Kisaran (hari) \\
\hline 1 & Larva instar-1 & $9,33 \pm 0,71$ & $8-10$ \\
2 & Larva instar-2 & $4,89 \pm 0,60$ & $4-6$ \\
3 & Larva instar-3 & $6,44 \pm 0,88$ & $5-8$ \\
4 & Larva instar-4 & $10,44 \pm 1,13$ & $9-12$ \\
5 & Prapupa & $2,67 \pm 0,50$ & $2-3$ \\
6 & Pupa & $7,33 \pm 0,71$ & $6-8$ \\
7 & Imago betina & $71 \pm 5,05$ & $63-76$ \\
8 & Imago jantan & $61,44 \pm 6,62$ & $52-69$ \\
\hline
\end{tabular}

Mangsa $B$. tabaci mempengaruhi lama hidup C. coeruleus. Lama hidup pada tahap larva $C$. coeruleus dengan mangsa $B$. tabaci lebih lama dibandingkan dengan mangsa $H$. cubana (Oka dkk., 1987), sedangkan lama hidup imago betina dan jantan tidak jauh berbeda. Menurut Oka dkk. (1987) lama hidup $C$. coeruleus dengan mangsa $H$. cubana yaitu 3,11 hari untuk larva instar-1; larva instar-2 2,89 hari; larva instar-3 3,11 hari; larva instar-4 6,41 hari; prapupa 2,18 hari; pupa 6,70 hari; imago betina 73,75 hari dan imago jantan 71,25 hari. Makanan diduga menjadi faktor yang mempengaruhi perbedaan tersebut. Hodek \& Honek (1996) mengemukakan bahwa jenis dan kualitas makanan mempengaruhi waktu perkembangan pada tiap tahap perkembangan famili Coccinellidae. Kandungan gizi dari makanan tersebut berpengaruh terhadap pertumbuhan, perkembangan, kesuburan, mortalitas dan keperidian serangga (Sunjaya, 1970).

\section{Keperidian $C$. coeruleus}

Jumlah telur yang diletakkan seumur hidup C. coeruleus dengan mangsa $B$. tabaci berkisar antara 11-116 butir. Pada kepadatan mangsa 120 ekor, 240 ekor dan 480 ekor, jumlah telur yang diletakkan adalah berturut-turut 11 butir, 88 butir, dan 116 butir.

Selama hidupnya, C. coeruleus meletakan telur sebanyak 2-6 kali. Pada kepadatan mangsa 120 ekor, terjadi 2 kali peletakan telur sedangkan pada kepadatan 240 ekor dan 480 ekor, peletakan telur terjadi sebanyak 6 kali. Di setiap peletakan, telur diletakkan satu per satu dan berkelompok dengan jumlah antara 2-26 butir. Menurut Clausen (1972), pada umumnya famili Coccinellidae meletakkan telur dalam bentuk kelompok dengan kisaran 10 - 50 butir. Dalam penelitian ini terlihat bahwa peningkatan jumlah mangsa $B$. tabaci meningkatkan jumlah telur yang diletakkan imago betina. Hasil ini sejalan dengan penelitian Hodek \& Honek (1996) bahwa jumlah telur yang diletakkan oleh famili Coccinellidae bergantung pada jumlah makanan yang dikonsumsi imago.

Persentase penetasan telur pada kepadatan mangsa 120 ekor nimfa $B$. tabaci adalah 54,55\% lebih sedikit dibandingkan dengan persentase penetasan telur pada kepadatan mangsa 240 ekor (80,68\%) dan 480 ekor (81,03\%). Diduga jumlah energi yang dikandung oleh telur tersebut kurang mencukupi untuk proses penetasan. Waktu yang dibutuhkan dari imago sampai bisa meletakkan telur untuk pertama kali pada kepadatan mangsa 120 ekor, 240 ekor, dan 480 ekor adalah berturut-turut 45 hari, 30 dan 20 hari. Stadium telur berkisar antara 6-7 hari dengan rata-rata 6,44 hari. Oka dkk., (1987) mengemukakan bahwa stadium telur $C$. coeruleus dari imago yang diberi mangsa $H$. cubana adalah 7 hari.

Dalam penelitian ini dapat diketahui bahwa siklus hidup $C$. coeruleus dari tahap telur sampai imago meletakkan telur pertama kali berkisar antara 67,55-92,55 hari dengan rata-rata 79,22 hari. Hasil penelitian yang dilakukan Oka dkk., (1987) menunjukkan bahwa siklus hidup $C$. coeruleus dengan mangsa $H$. cubana adalah 48,60 hari. 
Tabel 2. Kemampuan memangsa $C$. coeruleus terhadap B. tabaci (ekor hari ${ }^{-1}$ ) dihubungkan dengan tahap perkembangan predator dan kepadatan mangsa

\begin{tabular}{ccccccc}
\hline \multirow{2}{*}{$\begin{array}{c}\text { Kepadatan } \\
\text { mangsa }\end{array}$} & $\begin{array}{c}\text { Larva } \\
\text { instar-1 }\end{array}$ & $\begin{array}{c}\text { Larva } \\
\text { instar-2 }\end{array}$ & $\begin{array}{c}\text { Larva } \\
\text { instar-3 }\end{array}$ & $\begin{array}{c}\text { Larva } \\
\text { instar-4 }\end{array}$ & $\begin{array}{c}\text { Imago } \\
\text { betina }\end{array}$ & $\begin{array}{c}\text { Imago } \\
\text { jantan }\end{array}$ \\
\hline \multirow{2}{*}{60 ekor } & $3,31 a$ & $21,5 a$ & $38,95 a$ & $53,47 b$ & $37,56 a$ & $32,67 a$ \\
& $\mathrm{D}$ & $\mathrm{C}$ & $\mathrm{AB}$ & $\mathrm{A}$ & $\mathrm{AB}$ & $\mathrm{BC}$ \\
\multirow{2}{*}{120 ekor } & $4,95 a$ & $14,61 a$ & $40,4 a$ & $71,13 a b$ & $40,72 a$ & $36,83 a$ \\
& $\mathrm{E}$ & $\mathrm{D}$ & $\mathrm{B}$ & $\mathrm{A}$ & $\mathrm{BC}$ & $\mathrm{BC}$ \\
240 ekor & $5,5 a$ & $20,17 a$ & $25 a$ & $102,5 a$ & $54,55 a$ & $38,9 a$ \\
& $\mathrm{E}$ & $\mathrm{D}$ & $\mathrm{CD}$ & $\mathrm{A}$ & $\mathrm{BC}$ & $\mathrm{BC}$ \\
\hline
\end{tabular}

Keterangan : Imago betina dan imago jantan berumur 1-7 hari.

Nilai rata-rata yang diikuti oleh huruf kecil yang sama ke arah vertikal dan huruf besar yang sama ke arah horizontal menunjukkan tidak berbeda nyata menurut Uji Jarak Berganda Duncan pada taraf nyata 5\%.

Menurut Clausen (1972), faktor makanan dapat memperpendek atau memperpanjang siklus hidup famili Coccinellidae.

\section{Tingkat Predasi C. coeruleus Terhadap B. tabaci}

Kemampuan memangsa $C$. coeruleus terhadap nimfa $B$. tabaci dipengaruhi oleh tahap perkembangan $C$. coeruleus dan pengaruh tersebut bergantung pada kepadatan mangsa. Pada Tabel 2 terlihat bahwa tahap perkembangan predator berpengaruh terhadap jumlah mangsa yang dimangsa, sedangkan kepadatan mangsa tidak berpengaruh terhadap jumlah mangsa yang dimangsa, kecuali pada larva instar-4. Kemampuan memangsa larva instar-1 dan larva instar-2 lebih sedikit dibandingkan larva instar-3, larva instar-4, imago betina dan imago jantan. Aktivitas metabolisme larva instar-1 dan larva instar-2 dengan larva instar- 3 , larva instar-4, imago betina dan imago jantan sangat berbeda. Perbedaan aktivitas metabolisme tersebut mempengaruhi perilaku serangga dalam proses pemangsaan. Menurut Smith (1978) dalam Martiny (1988), tahap perkembangan dan umur sangat menentukan perilaku serangga, sebagai akibat perbedaan aktivitas metabolisme yang besar antara serangga tua dan muda serta tingkat pertumbuhan serangga tersebut.

Kemampuan memangsa larva instar-4 lebih tinggi dibandingkan dengan tahap perkembangan lainnya. Larva instar-4 membutuhkan makanan lebih banyak untuk memasui tahap selanjutnya yaitu tahap pupasi. Pada pemberian mangsa Planococcus lilacinus yang dilakukan oleh Emiwaty (1989), larva instar-4 C. coeruleus menunjukkan karaktersitik yang serupa. Hodek \& Honek (1996) mengemukakan bahwa kebutuhan energi untuk proses metabolisme pada larva instar-4 lebih besar dibandingkan tahap perkembangan lainnya untuk persiapan pupasi.

\section{SIMPULAN}

Waktu perkembangan larva instar-1 Curinus coeruleus yang diberi mangsa nimfa Bemisia tabaci berkisar antara 8-10 hari, larva instar-2 berkisar 4-6 hari, larva instar-3 berkisar 5-8 hari, larva instar-4 berkisar 9-12 hari, prapupa berkisar $2-3$ hari, pupa berkisar 6-8 hari, lama hidup imago betina berkisar 63-76 hari dan imago jantan berkisar antara 52-69 hari. Kemampuan C. coeruleus meletakkan telur selama hidupnya adalah berkisar antara 11-116 butir dengan persentase penetasan telur 54,55-81,03\%, peletakan telur terjadi 2-6 kali. Masa inkubasi telur berkisar antara 6-7 hari.

Kemampuan memangsa $C$. coeruleus terhadap nimfa $B$. tabaci dipengaruhi oleh tahap perkembangan $C$. coeruleus dan pengaruh tersebut bergantung dari kepadatan mangsa. Larva instar-4 $C$. coeruleus menunjukkan tanggap fungsional pada peningkatan kepadatan mangsa $B$. tabaci. Jumlah pemangsaan tertinggi terjadi pada perlakuan larva instar-4 dengan kepadatan mangsa 240 ekor nimfa $B$. tabaci, yaitu 102,5 ekor nimfa $B$. tabaci per 1 larva instar-4 C. coeruleus per hari. 


\section{DAFTAR PUSTAKA}

Aidawati, N. 2001. Penularan Virus Krupuk Tembakau dengan Bemisia tabaci Gennadius (HEMIPTERA: ALEYRODIDAE). Tesis. Institut Pertanian Bogor. http://tumoutou.net.htm (diakses 27 November 2007).

Clausen, CP. 1972. Entomophagous Insects. Reprinted Hafner Publishing Company. New York. 688p.

Dixon, AFG. 2000. Insect Predator-Prey Dynamics; Ladybird Beetles and Biological Control. University of East Anglia. Cambridge University Press. Cambridge.

Fatah, A. 2007. Inventarisasi Parasitoid dan Predator Kutu Kebul Bemisia tabaci Gennadius pada Beberapa Komoditas Tanaman di Kecamatan Ciwidey Kabupaten Bandung. Skripsi Program Sarjana Fakultas Pertanian Universitas Padjadjaran. 69 Hal.

Hodek. I and A. Honek., 1996. Ecology of Coccinellidae. Kluwer Academic Publisher. Dordrecht, Netherlands. 464p.

Martiny, N. 1988. Kemampuan Pemangsaan Predator Curinus coeruleus Mulsant (Coleoptera: Coccinellidae) Pada Berbagai Kepadatan Populasi Telur Kutu Loncat Lamtoro Heteropsylla cubana Crawford (Homoptera: Psyllidae). Skripsi Jurusan Hama dan Penyakit Tumbuhan, Fakultas Pertanian, Institut Pertanian Bogor. Bogor.
Mau, RFL. and JLM. Kessing. 1992. Bemisia tabaci (Gennadius). Crop Knowledge Master. http://www.extento.hawaii.edu. Diakses 9 Februari 2008

Oka, IN., AH. Bahagiawati, AANB. Kamandalu dan IB. Suatika. 1987. Biologi Curinus coeruleus Mulsant (Coleoptera: Coccinellidae) Predator kutu loncat Heteropsylla spp. (homoptera: Psyllidae). Kongres Entomologi III, Jakarta, 30 September - 2 Oktober 1987. Jakarta.

Sheppard, SK. and JD. Harwood. 2005. Advances in molecular ecology: tracking trophic links through predator-prey food-webs. Functional Ecology. British Ecology Society. 19:751-762.

Sosromarsono, S. dan K. Untung. 2006. Keanekaragaman Hayati Artropoda Predator dan Parasit di Indonesia dan Pemanfaatannya. http://kasumbogo.staff.ugm.ac.id (diakses 2 Oktober 2007).

Sunjaya, PI. 1970. Dasar-dasar Ekologi Serangga. Bagian Ilmu Hama Tumbuhan. Institut Pertanian Bogor. Bogor.

Untung, K. 2001. Pengantar Pengelolaan Hama Terpadu. Gajah Mada university Press. Yogyakarta.

Wagiman, FX. 1996. Respon Fungsional Menochilus sexmaculatus Fabricus Terhadap Aphis gossypii Glover. Jurnal Perlindungan Tanaman Indonesia, 2: 38-43. 